\title{
Learning Outcomes Improvement of Javanese Language Material Wayang Figures through STAD Learning Model with Interactive Learning Media Based on Macromedia Director
}

\author{
Resy Susanti ${ }^{1}$, Kun Winarti ${ }^{2}$, Anggi Hary Prasadi ${ }^{3}$, Alvina Nihayatul Husna ${ }^{4}$ \\ 1,2,3,4 Graduate School Universitas Negeri Semarang, Indonesia \\ ${ }^{1}$ Corresponding email: resysusanti@gmail.com
}

\begin{abstract}
This study aims to describe the improvement of learning outcome of Javanese language material, wayang figures, through STAD learning model with interactive learning media based on Macromedia Director in grade 4 students of SDN Mranggen 1 in the $2^{\text {nd }}$ semester of 2014/2015 academic year. The instruments used in this study were formative test results to assess learning outcomes and observation sheet learners learning activities. This study was conducted in 2 cycles. Each cycle consisted of 4 stages: planning, implementation, observation and reflection. The data analysis method used in this study was descriptive comparative. The results showed improvement of students' learning outcomes. Before the action was given, average value was just 56.94 with $30.56 \%$ of classical completeness. In learning cycle 1 the average value increased to 72.78 with a classical completeness of $66.67 \%$. In cycle 2 the average value increased again to 81.11 with classical completeness of $88.89 \%$.
\end{abstract}

Keyword: STAD, macromedia director, Javanese language

\section{Introduction}

Today there is a tendency that Javanese language lessons are considered subjects that are not important. Sometimes Javanese language lessons are allocated for other subjects especially in elementary schools in order to achieve other subjects' competencies. As a result, Javanese language is considered low and far from expectations.

Low learning outcomes of the Javanese language subjects also occurr in fourth grade students of SDN Mranggen I on the 2014/2015 academic year, especially material related to wayang figures. Based on daily test of 36 students, only 11 students scored above the KKM (Criterion Completeness Minimum) in which the established KKM was 70. In addition, the average grade was also very apprehensive, which was 56.94 .

Such condition can create anxiety for teachers, so teachers are encouraged to perform an action in the form of Classroom Action Research (PTK) in order to improve the learning outcomes of the Javanese language. After going through a series of observations and reflections on learning Javanese language, it is obtained result that learning outcomes Javanese language is still low, both from the side of teachers and from the side of learners themselves.

From the side of teachers, it turns out that during this time teachers have not used media in delivering material. In addition the teaching methods that teachers use are less varied and tend to be monotonous. Teachers mostly use lecture methods, and a little questioning. This is done repeatedly, causing boredom in the learners. From the students' perspective, although the majority of learners come from the Javanese, it turns out they still have lack of knowledge of the Javanese language. So far Javanese language is only used as a language conversation. Whereas Javanese is a language which is rich in meanings and has a level of usage, such as "ngoko" used for conversations with peers, "krama inggil" is used for conversations with older people, and much more.

The results of observation also indicate that many learners consider the subjects of Java language is an ancient subject and unlikely able to follow the development of the era. Even, there is a perception that the Javanese language is a difficult subject because the language is difficult to understand. Therefore, the activeness and motivation to learn learners in learning the Java language are still low. And due to low activeness and motivation of this learning motivation, the learning results obtained are also considered low.

After knowing the cause of the low learning outcomes of Javanese Language learners, the teachers need to find a solution or appropriate methods and media to deliver the subject matter. Of the many methods and 
learning media available is STAD learning model (Student Team Achievement Division) with interacative learning media based on Macromedia Director in doing Javanese language learning, especially wayang figures material.

The use of STAD learning model with interactive learning media based on Macromedia Director is expected to improve students' activeness and motivation of learning on Javanese language subject material wayang figures. With increasing activeness and learning motivation learners expected the learning outcomes achieved also increased.

The formulation of the problem of this research are: 1) How are learning process with STAD learning model using interactive learning media on Javanese language subjects wayang figures material for students of class IV conducted?; and 2) How much is the increasing result of learning Javanese language subjects wayang figures with STAD learning model using interactive media in class IV?

The purpose of this study are: 1) describing the learning process with STAD learning model using interactive learning media on Javanese language subjects puppet characters for students of class IV; and 2) describing the improvement of learning result of Javanese language lesson of puppet show with STAD learning model using interactive media in IV grade students

\section{Methods}

The subjects of this study were students of class IV SDN Mranggen 1 semester 2 year lesson 2014/2015 consisting of 13 female students and 23 male students, so that the total was 36 students. This research took place in SD $\mathrm{N}$ Mranggen 1 which is located at Jalan Raya Mranggen No. 162, Mranggen District, Demak District.

The study was conducted in 2 cycles, in which cycle 1 was conducted on February 14 and 21,2015 , and cycle 2 was conducted on February 28, 2015 and March 7, 2015 with wayang figures material.

Sources of research data were 1) students, 2) class teachers, and 3) peers. The data obtained were 1) a list of values, 2) field data records, 3) observation sheets, and 4) documentation as long as the action was given. Test was used to determine the improvement of learners' learning outcomes during the Javanese action learning activities of puppet characters. Non-test techniques in the form of observations with observation sheets and field notes were used to assess the activities of learners during the activities performed. The data collection tool depended on the technique used. In terms of test technique, the tool can take the form of test items. In terms of non-test technique, the tool can be in the form of guidance, success indicator, and observation sheet.

In this study examination of data validity was done by triangulation (triangulation), peer debriefing (peer debriefing), and the use of accurate reference (referention adequancy). During the validity of peers, peers analyzed and corrected the problems that have been prepared before the researchers used the research. The results of peer validation stated that the questions were appropriate to evaluate learners' learning outcomes in puppet material.

Data analysis technique used in this research was comparative descriptive analysis, where data was presented through tables and graphs that were described, then compared. The calculation of students' activity measurements and the calculation of learning outcomes of learners used simple statistics.

The study consisted of cycling cycle, where each cycle consists of 4 stages: planning, execution, observation and reflection. The explanation of each research cycle is presented as follows. 1) In planning, after identifying and formulating problems that occur in the classroom, the researcher planned to improve learning by using STAD learning model with interactive learning media. 2) In action / implementation stage, teachers take corrective action in accordance with the steps that exist in the lesson plan. 3) In observation stage, teachers and peers make observations of the learners' activities during the learning process takes place. Aspects observed were enthusiasm in learning, learners' attention during teacher's explanation, courage to ask, courage express opinions, willingness to read the material, willingness to do tasks, and cooperation in groups. Observations were made using observation sheets and field data records. 4) In reflection stage, reflection or contemplation was done to determine the effectiveness and success of actions performed by teachers. Rafleksi was done by using learning outcomes derived data value learners and observation sheets and field data records. From these data, it can obtained whether the methods and learning media used successfully solved existing problems or not. If learning outcomes were in accordance with the 
target set then the actions performed were said to be successful. However, if the activity and learning outcomes achieved have not reached improvement in cycle 2 is needed.

Indicators of success in this study are in the form of improving learning outcomes of learners on the subjects of Javanese language puppet material. There are 2 indicators of success in this study, the average value of daily re-examination of learners above 70 and classical completeness of learners more than $80 \%$.

\section{Results And Discussion}

\section{Description Early Condition Learners}

Prior to the improvement of learning, teachers do learning by lecture method and frequently asked questions. In addition, teachers also have not used the media in learning.Adapun learning results obtained before the action can be seen from table 4.1.

Table 1. Results learned before action

\begin{tabular}{ccc}
\hline No & Value Range & $\begin{array}{c}\text { The number of } \\
\text { students }\end{array}$ \\
\hline 1 & $\leq 50$ & 14 \\
2 & $51-60$ & 11 \\
3 & $61-70$ & 6 \\
4 & $71-80$ & 3 \\
5 & $81-90$ & 1 \\
6 & $91-100$ & 1 \\
& Amount & 36 \\
Grade average value & 56,94 \\
Number of completed & 11,00 \\
students & $30,56 \%$ \\
Classical mastery & 18,18 \\
Standard deviation &
\end{tabular}

Based on table 1 above shows that as many as 14 people learners are in the range of values $0-50,11$ students there are in the range of 5160,6 students there are in the range of 61 to 70 , 3 students in the range of values $71-80,1$ learner in the range of values 81-90, and 1 learner is in the range of values $91-100$. And the average grade value of 56.94 .

\section{Description of Cycle 1}

Cycle 1 is done on February 14 and 21, 2016. The learning result in cycle 1 can be seen in table 2 .
Table 2. Results of learning cycle 1

\begin{tabular}{ccc}
\hline No & Value Range & $\begin{array}{c}\text { The number } \\
\text { of students }\end{array}$ \\
\hline 1 & $\leq 50$ & 0 \\
2 & $51-60$ & 12 \\
3 & $61-70$ & 11 \\
4 & $71-80$ & 5 \\
5 & $81-90$ & 7 \\
6 & $91-100$ & 1 \\
& Amount & 36 \\
& Grade average & 72,78 \\
& value & 24,00 \\
& Number of & \\
& completed & \\
& students & $66,67 \%$ \\
& Classical mastery & 12,10 \\
\hline
\end{tabular}

Table 2 above shows that no students gain a score of 50.12 Learners score in the 51 to 60 score range. 11 Learners are in the 61 to 70 score range. 5 Learners are in the 71 to 80 score range. The learner is in the range of values 81 90, and 1 learner in the range of values $91-100$. The average grade value of 72.78 , the total number of students who completed 24 children so that the classical completeness $66.67 \%$.

From data of learning result of cycle 1 nlai mean of class equal to 72,78 have fulfilled indicator of success which is determined that is more than 70. But classical completeness in cycle 1 equal to $66,67 \%$ not yet fulfill indicator of success that is more than $80 \%$. It is therefore necessary to improve the learning of cycle 2 .

\section{Description of Cycle 2}

Cycle 2 was conducted on February 28 and March 7, 2016. The result of learning cycle 2 is in table 3 .

Table 3. Results of learning cycle 3

\begin{tabular}{ccc}
\hline No & Value Range & $\begin{array}{c}\text { The number of } \\
\text { students }\end{array}$ \\
\hline 1 & $\leq 50$ & 0 \\
2 & $51-60$ & 4 \\
3 & $61-70$ & 7 \\
4 & $71-80$ & 13 \\
5 & $81-90$ & 5 \\
6 & $91-100$ & 7 \\
Amount & 36 \\
Grade average value & 72,78 \\
Number of completed & 24,00 \\
students & $66,67 \%$ \\
Classical mastery & 12,10 \\
Standard deviation &
\end{tabular}


Table 3 shows that in cycle 2, 4 students get a score in the range of $51-60.7$ Learners are in the 61 to 70 score range. 13 Learners are in the 71 to 80 score range. 5 Learners are in the range of $81-90.7$ Students are in the range of values $91-100$. The average grade achieved is 81.11. The number of students who completed 32 children, so that the classical execution $88.89 \%$.

Based on the data of learning cycle 2, the average value of kleas of 81.11 has met the success indicator that is greater than 70 . While the classical completeness of $88.89 \%$ also meets the succeeding indicator is greater than $80 \%$. Therefore, there is no need to improve the learning of the next cycle. Comparison of learning outcomes of learners before the action, cycle 1 , and cycle 2 can be seen in table 4 .

Table 4. Comparison of participants' learning outcomes before the action, cycle 1 , and cycle 2 .

\begin{tabular}{clccc}
\hline No & Information & $\begin{array}{c}\text { Before } \\
\text { Action }\end{array}$ & Cycle 1 & $\begin{array}{c}\text { Cycle } \\
\mathbf{2}\end{array}$ \\
\hline 1 & $\begin{array}{l}\text { average grade } \\
\text { value } \\
\text { the number of } \\
\text { students }\end{array}$ & 56,94 & 72,78 & 81,11 \\
3 & $\begin{array}{l}\text { completed } \\
\text { classical } \\
\text { mastery } \\
\text { minimum } \\
\text { value } \\
\text { maximum }\end{array}$ & $30,56 \%$ & $66,67 \%$ & $88,89 \%$ \\
value & 100 & 100 & 100 \\
\hline
\end{tabular}

Table 4 shows that before the action, the average grade is 56,94 , at cycle 172,78 , and in cycle 2 is 81,11 . The number of learners completed before the action is 11 children, in cycle 1 a number of 24 children, and in cycle 2 a number of 32 children. The classical completeness that the learner achieves before the action is $30,56 \%$, in cycle 1 equal to $66,67 \%$, and in cycle 2 equal to $88,89 \%$. The minimum value before the action is 20 , in cycle 1 of 60 , and on cycle 2 of 60 . The maximum value achieved before the action, cycle 1 , and cycle 2 is 100 .

Table 4 shows that learning outcomes obtained by learners have improved from before action, cycle 1, and cycle 2. Based on observations during the course of the study this is due to the level of interest of learners on the increased learning. Evident when learning takes place the students look so enthusiastic, when the question and answer session of many children who point finger, attention and concentration of learners is very high. They are also very interested in the media and the methods teachers use in delivering puppet material. While working on interactive quizzes in groups they also look very excited. The joy when the question they answer is true is very visible. Learning Javanese material puppet characters took place very fun. So it is not surprising that the value of formative tests obtained also increases in each cycle. This is in line with the opinion of Tania (2013) which states that interactive learning media can improve the quality of learning outcomes of learners.

The data of the research shows that the steps taken in the process of learning Java Language puppet puppet material using STAD learning model with interactive media based on Macromedia Director able to improve learning outcomes of learners. Then the first hypothesis which reads that the steps of learning process of puppet characters through STAD learning model with interactive learning media allegedly can improve the learning outcomes of students of class V SD Negeri Mranggen 1 semester 2 year lesson 2014/2015 proved true. Likewise, the second hypothesis that the learning process through STAD learning model with interactive learning media subjects Javanese language material puppet characters allegedly able to improve student learning outcomes class V SDN Mranggen 1 Semester 2 year lesson 2014/2015 also proved true.

\section{Conclusion}

Some conclusions can be derived from the results of this research. 1) Steps of learning process of wayang puppet material through STAD learning model with interactive learning media allegedly can improve student learning result of class V SD Negeri Mranggen 1 semester 2 year lesson 2014/2015. 2) Learning process through STAD learning model with interactive learning media based on Macromedia Director on Javanese language subjects of puppet characters is able to improve learning outcomes of students of class V SDN Mranggen 1 Semester 2 year lesson 2014/2015 from the average grade grade of 56.94 with classical thoroughness $30,56 \%$ on learning before action, increased to 72.78 with classical completeness equal to $66.67 \%$ in cycle 1 , and increased again to 81.11 with classical completeness $88.89 \%$ in cycle 2. 3) STAD 
learning model with interactive learning media based on Macromedia Director can increase the interest of learners to material puppet characters. 4) STAD learning model with interactive learning media based on Macromedia Director make learning fun.

\section{Refferences}

Bloom, B.E (Ed). (1984). Taxonomy of Educational Objectives. New York: Longman., Inc

Dahlan, M.D. (1990). Model-Model Mengajar. Bandung: CV. Diponegoro.

Daryanto. (2013). Media Pembelajaran: Peranannya Sangat Penting Dalam Mencapai Tujuan Pembelajaran. Yogyakarta: Gava Media

Gagne, R.M. (1985). The Conditions of Learning and Theory of Instruction. New York: Holt Rinehart and Winston.

Hasan, H.S. (1995). Pendidikan Ilmu Sosial. Jakarta: Proyek Pendidikan Tenaga Akademik

Joyce, B., Well, M., Calhoun, E. (2000). Model of Theaching. London: Allyn and Bacon

Minarti. (2011). Peningkatan Keterampilan Membaca Aksara Jawa Melalui Pembelajaran Interaktif Berbantuan Macromedia Flash Pada Siswa Sekolah Dasar. Final Project.

Munir. (2008). Kurikulum Berbasis Teknologi Informasi dan Komunikasi. Bandung:Alfabeta
Nurrohmah. (2014). Peningkatan Hasil Belajar Bahasa JawaPokok Bahasan Aksara Jawa melalui Penggunaan Multimedia Interaktif pada Siswa Kelas IV Semester II Di MI Ma'arif NU O1 Cilongok Kabupaten Banyumas Tahun Pelajaran 2013/2014. Skripsi

Slavin, Robert. (2005). Cooperative Learning. London: Allymand Bacon.

Sudjana, Nana. 1987. Dasar-dasar Proses Belajar Mengajar. Bandung: Sinar Baru Algesindo Offset

Suprijono, Agus. (2009). Cooperative Learning teori dan Aplikasi PAIKEM. Yogyakarta : Pustaka Pelajar.

Tintin Prihatiningsih. (2006). Peningkatan Keaktifan Siswa dalam Pembelajaran Matematika Melalui Model Pembelajaran Kooperatif tipe STAD (Student Teams Achievement Division) pada pokok bahasan bilangan bulat kelas VII A SMP Negeri 5 Depok Yogyakarta. Skripsi.

http://istiyanto.com/pengertian-dan-manfaatmultimedia-pembelajaran/ downloaded on 4 February 2015 at 13.32

http://pengertianwayang.blogspot.co.id/ downloaded on 4 February at 15.03

http://tania91.ilearning.me/laporan-kkp/bab-ii/28-media-pembelajaran-interaktif/ downloaded on 5 February 2015 at19.30 